\title{
PENGARUH MODEL PEMBELAJARAN STUDENT FACILITATOR AND EXPLAINING BERBANTUAN PETA KONSEP TERHADAP KOMPETENSI PENGETAHUAN IPA SISWA
}

\author{
Ni Putu Dessy Wiranti, Ni Wayan Suniasih, I Wayan Darsana \\ Program Studi Pendidikan Guru Sekolah Dasar, Universitas Pendidikan Ganesha \\ E-mail:dessywiranti42488@gmail.com,niwayan.suniasih@undiksha.ac.id,w_darsana@ymail.com@undiksha.ac.id
}

\begin{abstract}
Abstrak
Penelitian ini bertujuan untuk mengetahui pengaruh model pembelajaran student facilitator and explaining berbantuan peta konsep terhadap kompetensi pengetahuan IPA siswa kelas IV SD Gugus Kolonel I Gusti Ngurah Rai Denpasar Utara tahun pelajaran 2016/2017. Penelitian ini merupakan penelitian eksperimen dengan rancangan penelitian yang digunakan adalah rancangan Kelompok Non-ekuivalen. Populasi dalam penelitian ini adalah seluruh siswa kelas IV yang berjumlah 478 siswa. Sampel penelitian ini sebanyak 66 siswa yang ditentukan menggunakan teknik sampel kelompok. Metode pengumpulan data dalam penelitian ini adalah metode tes. Data yang diperoleh dianalisis menggunakan uji-t dengan rumus separated varians. Hasil penelitian berdasarkan analisis data, diperoleh harga $t_{\text {hitung }}=3,25>t_{\text {tabel }}=2,00$ dengan taraf signifikan 5\% dan dk $=64$, maka $\mathrm{H}_{0}$ ditolak dan $\mathrm{H}_{\mathrm{a}}$ diterima. Hal ini membuktikan bahwa terdapat perbedaan yang signifikan kompetensi pengetahuan IPA antara kelompok eksperimen dan kelompok kontrol pada kelas IV SD Gugus Kolonel I Gusti Ngurah Rai Denpasar Utara tahun pelajaran 2016/2017. Nilai rata-rata juga menunjukkan bahwa kompetensi pengetahuan IPA yang diperoleh siswa kelompok eskperimen $\bar{X}=0,56>\bar{X}=0,43$ siswa kelompok kontrol. Dengan demikian dapat disimpulkan bahwa model pembelajaran student facilitator and explaining berbantuan peta konsep berpengaruh terhadap kompetensi pengetahuan IPA siswa kelas IV SD Gugus Kolonel I Gusti Ngurah Rai Denpasar Utara tahun pelajaran 2016/2017.
\end{abstract}

Kata kunci: student facilitator and explaining, peta konsep, kompetensi pengetahuan IPA

\begin{abstract}
This research aim is to know the influence of student facilitator and explaining learning model with the essistance of concept map toward the knowledge science competence in fourth grade students of SD Gugus Kolonel I Gusti Ngurah Rai North Denpasar in lesson year 2016/2017. This research is an experiment with the research design used is non-equivalent group design. The populations of this research are all of the students in fourth grade which amount 478 students. The sample of the research is 66 students which determined with group sample technique. Data collection method in this research is test method. The data then was analized by used t-test with separated variants formulation. The result of the research based on data analyze, there was obtained $t_{\text {count }}=3,25>t_{\text {table }}=2,00$ with significant level $5 \%$ and $d k=64$, so that $\mathrm{H}_{0}$ is rejected and $\mathrm{H}_{\mathrm{a}}$ is accepted. It prove that the is a significant defference of knowledge science competence between experimental group and control group in fourth grade of SD Gugus Kolonel I Gusti Ngurah Rai North Denpasar in lesson year 2016/2017. The average of the score also shows that knowledge science competence students experimental group $\bar{X}=0,56>\bar{X}=0,43$ control grup. Therefore, it can be concluded that student facilitator and explaining learning model with the essistance of concept map influences the knowledge science competence in fourth grade students of SD Gugus Kolonel I Gusti Ngurah Rai North Denpasar in lesson year 2016/2017.
\end{abstract}

Keywords: student facilitator and explaining, concept map, knowledge science competence

\section{Pendahuluan}

Pendidikan sangat penting bagi kemajuan suatu negara. Peningkatan kualitas sumber daya manusia dapat dilihat kemajuan negara dari segi sarana dan prasarana pendidikan. Keberhasilan pendidikan dipengaruhi oleh perubahan dan pembaharuan segala komponen pendidikan. Suardi (2016:71) menyatakan "pendidikan adalah usaha sadar dan terencana untuk mewujudkan suasana belajar dan proses pembelajaran agar peserta didik secara aktif mengembangkan potensi dirinya untuk memiliki kekuatan spiritual keagamaan, pengendalian diri, kepribadian, kecerdasan, akhlak mulia, serta keterampilan yang diperlukan dirinya, masyarakat, bangsa dan negara".

Komponen pendidikan tersebut meliputi kurikulum, guru, sarana prasarana, siswa dan model pembelajaran yang tepat untuk mewujudkan mutu pendidikan yang lebih baik. Mutu pendidikan di Indonesia 
telah diupayakan pemerintah untuk mengoptimalkan tercapainya tujuan pendidikan, salah satunya adalah penetapan kurikulum.

Pada kurikulum 2013, proses pembelajaran yang diterapkan di sekolah dasar adalah pembelajaran tematik terpadu. Implementasi tematik terpadu dilaksanakan dengan menggunakan pendekatan saintifik. Pembelajaran dengan pendekatan saintifik adalah proses pembelajaran yang dirancang agar siswa aktif melalui tahapan mengamati, menanya, mengumpulkan informasi, mengasosiasi, dan mengkomunikasikan (Kurniasih dan Sani, 2014:29). Pada pelaksanaan pembelajaran dengan pendekatan saintifik, pendidik perlu merancang berbagai kegiatan sesuai dengan karakteristik anak usia SD pada umumnya meliputi senang bergerak, senang bermain, senang melakukan sesuatu secara langsung dan senang bekerja dalam kelompok. Pembelajaran melalui beberapa kegiatan dapat mengembangkan rasa ingin tahu peserta didik dalam berbicara dengan kegiatan bertanya dan mengembangkan kemampuan berpikir dengan mengumpulkan informasi (Daryanto, 2014).

Berdasarkan informasi yang diperoleh dari seluruh guru kelas IV di SD Negeri Gugus Kolonel I Gusti Ngurah Rai Denpasar Utara dalam proses pembelajaran berkaitan dengan muatan materi IPA terdapat permasalahan yang terletak pada kurangnya kemampuan menanya dan mengomunikasikan pada saat proses pembelajaran berlangsung sehingga berpengaruh pada kompetensi pengetahuan yang dimiliki siswa. Kondisi ini tentu akan menciptakan kurangnya partisipasi siswa sehingga beberapa siswa menjadi kurang aktif dalam pembelajaran. Akibatnya pemahaman siswa dalam kegiatan pembelajaran kurang berkembang secara optimal dan berpengaruh terhadap kompetensi pengetahuan yang dicapai oleh siswa.

Oleh sebab itu, kemampuan siswa dalam memperoleh kompetensi pengetahuan harus dikembangkan secara optimal khususnya berkaitan dengan muatan materi IPA. Selain itu diperlukan model yang inovatif dan media untuk mendukung proses pembelajaran sesuai dengan karakteristik siswa. Salah satu model pembelajaran untuk mengoptimalkan kompetensi pengetahuan siswa yaitu model pembelajaran student facilitator and explaining berbantuan peta konsep.

Menurut Shoimin (2014:183) berpendapat bahwa "model pembelajaran student facilitator and explaining merupakan salah satu tipe pembelajaran kooperatif yang menekankan pada struktur khusus yang dirancang untuk mempengaruhi pola interaktif peserta didik dan memiliki tujuan untuk meningkatkan penguasaan materi”. Penerapan model pembelajaran student facilitator and explaining harus bisa memperbanyak pengalaman serta meningkatkan keaktifan peserta didik. Gagasan dasar model pembelajaran ini adalah guru memiliki kemampuan dalam menyajikan atau mendemonstrasikan materi di depan siswa lalu memberikan mereka kesempatan untuk menjelaskan kepada teman-temannya (Huda, 2013:228).

Model pembelajaran ini dipadukan dengan menggunakan bantuan peta konsep agar penyajian materi lebih mudah dipahami. Menurut Aqib (2015:50) menyatakan "media pembelajaran adalah segala sesuatu yang dapat digunakan untuk menyalurkan pesan dan merangsang terjadinya proses belajar dari si pembelajar (siswa)". Salah satu media inovatif yang dapat dipadukan dengan model pembelajaran student facilitator and explaining dalam membantu siswa menghasilkan pembelajaran yang bermakna yaitu peta konsep. Peta konsep merupakan salah satu cara untuk memperlihatkan suatu proses berpikir menjadi sederhana. "Peta konsep merupakan suatu grafik keterwakilan tentang suatu konsep dan hubungannya dengan sub-aspek dalam konsep tersebut, yang merefleksikan suatu pemahaman tentang bagaimana suatu konsep berhubungan antara satu dan yang lain dan kepada suatu skema yang sudah ada" (Yusuf, 2015:289). Salah satu bentuk peta konsep adalah pohon jaringan (network tree) yang memuat ide-ide pokok dalam persegi empat dengan beberapa kata yang lain dituliskan pada garis penghubung yang menunjukkan hubungan antara ide-ide itu.

Model pembelajaran student facilitator and explaining berbantuan peta konsep memberikan kesempatan kepada siswa memperoleh informasi melalui pengalaman maupun pendapat dari orang-orang sekitarnya. Hal ini tentu membantu siswa menjadi lebih aktif dan memperoleh kompetensi pengetahuan yang lebih baik.

Kompetensi pengetahuan dapat dinyatakan sebagai kompetensi pada kemampuan berpikir untuk mengukur tingkat penguasaan siswa. Menurut Agung (2011:81) menyatakan "kompetensi merupakan penguasaan pengetahuan, sikap dan keterampilan tentang suatu objek tertentu (suatu mata pelajaran)". Salah satu muatan materi yang dapat mengukur kompetensi pengetahuan adalah muatan materi IPA. Pada hakikatnya, IPA merupakan ilmu yang mempelajari tentang alam (Sawatowa, 2016:3). Menurut Wisudawati dan Sulistyowati (2014:22) berpendapat IPA memiliki karakteristik khusus yang mempelajari fenomena alam yang faktual (factual), baik berupa kenyataan (reality) atau kejadian (events) dan hubungan sebab-akibatnya. IPA sebagai disiplin ilmu dan penerapannya dalam masyarakat menjadi penting. Berdasarkan pemaparan tersebut, dalam penelitian ini kompetensi pengetahuan IPA adalah kemampuan dasar terhadap penguasaan pada muatan materi IPA berdasarkan pengetahuan yang dimiliki oleh peserta didik. Oleh karena itu, kemampuan siswa dapat berkembang dengan mengoptimalkan kompetensi pengetahuan IPA.

Berdasarkan uraian tersebut, maka dikaji lebih luas dalam sebuah penelitian berjudul pengaruh model pembelajaran student facilitator and explaining berbantuan peta konsep terhadap kompetensi pengetahuan IPA siswa kelas IV Gugus Kolonel I Gusti Ngurah Rai Denpasar Utara. Adapun tujuan dalam penelitian ini adalah untuk mengetahui pengaruh model pembelajaran student facilitator and explaining berbantuan peta konsep 
terhadap kompetensi pengetahuan IPA siswa kelas IV SD Gugus Kolonel I Gusti Ngurah Rai Denpasar Utara tahun pelajaran 2016/2017.

\section{Metode Penelitian}

Penelitian ini dilaksanakan pada semester II di kelas IV SD Gugus Kolonel I Gusti Ngurah Rai Kecamatan Denpasar Utara. Waktu penelitian dilaksanakan mulai November 2016 sampai dengan Mei 2017. Penelitian ini tergolong penelitian kuantitatif dengan rancangan eksperimen kuasi (Quasi-Eksperimental Design). Pemilihan subjek penelitian pada rancangan ini, tidak selalu dapat dilakukan pemilihan subjek secara random (individual random) dan tidak memilih serta memilah subjek sesuai dengan rancangan dalam penetapan random (Setyosari, 2015:210). Bentuk rancangan eksperimen kuasi yang digunakan adalah Rancangan Kelompok Non-ekuivalen. Rancangan yang digunakan melibatkan dua kelompok kelas yaitu kelompok kelas eksperimen dan kelompok kelas kontrol. Satu kelompok kelas sebagai kelompok eksperimen mendapat perlakuan dan satu kelompok sebagai kelompok kontrol. Pada rancangan ini kedua kelompok yang akan diteliti diberikan pretest dan posttest. Pretest juga digunakan untuk penyetaraan kelompok. Hal ini sejalan dengan pendapat Dantes (2014:111) menyatakan bahwa "pemberian pretest biasanya untuk mengukur ekuivalensi atau penyetaraan kelompok". Pada penelitian yang tergolong penelitian kuantitatif pada umumnya menggunakan sampel yang diambil dari suatu populasi tertentu. Menurut Agung (2014:69) menyatakan bahwa "populasi adalah keseluruhan objek penelitian". Jadi kesimpulannya, populasi adalah keseluruhan dari objek yang akan diteliti untuk dipelajari dan ditarik kesimpulan. Berdasarkan pendapat tersebut, populasi dari penelitian ini adalah seluruh siswa kelas IV SD Gugus Kolonel I Gusti Ngurah Rai Denpasar Utara tahun pelajaran 2016/2017 yang terdiri dari 14 kelas dalam 6 sekolah dasar, diantaranya SD Negeri 1 Ubung, SD Negeri 2 Ubung, SD Negeri 3 Ubung, SD Negeri 4 Ubung, SD Negeri 5 Ubung, dan SD Negeri 6 Ubung. Jumlah populasi dari penelitian ini adalah 487 orang.

Populasi dan sampel dalam suatu penelitian memiliki hubungan yang saling berkaitan. "Sampel adalah bagian dari jumlah dan karakteristik yang dimiliki oleh populasi tersebut” (Sugiyono, 2016:81). Jadi, dapat disimpulkan bahwa sampel adalah bagian dari populasi yang dipilih dan diambil dengan menggunakan teknik tertentu.

Teknik sampling yang digunakan dalam menentukan sampel adalah teknik sampel kelompok. Teknik ini digunakan apabila populasi atau sampel yang tersedia berupa unit-unit rumpun yang biasanya dipakai karena tidak mungkin dilakukan dengan teknik acak. Pada pemilihan sampel penelitian ini dilakukan tanpa pengacakan individu melainkan pengacakan kelas karena kelas telah terbentuk sebelumnya. Penentuan sampel yang dipilih menjadi kelompok kontrol dan kelompok eksperimen dilakukan dengan cara pengundian. Pengundian dilakukan agar semua anggota populasi memiliki kesempatan yang sama untuk dipilih menjadi sampel penelitian. Untuk mendapatkan kelas yang akan dijadikan kelas eksperimen dan kelas kontrol, pengambilan sampel harus memenuhi syarat representatif, artinya sampel yang diambil benar-benar mewakili populasi yang ada. Setelah dilakukan undian diperoleh hasil dua kelompok yang akan digunakan sebagai sampel penelitian yaitu kelas IVA di SD Negeri 3 Ubung dan kelas IVB di SD Negeri 6 Ubung. Kedua kelompok ini kemudian diberi pretest dengan tujuan untuk menyetarakan kelompok eksperimen dan kelompok kontrol yaitu dengan menggunakan teknik matching. Darmadi (2014:234) menyatakan bahwa "matching adalah suatu teknik untuk menyeragamkan kelompok pada satu variabel atau lebih yang oleh peneliti telah diidentifikasikan mempunyai hubungan yang erat dengan variabel tidak bebas". Teknik yang dimaksud adalah memasangkan atau menjodohkan nilai pretest yang sama antara siswa di kelompok pertama dengan siswa di kelompok kedua, sehingga nilai masing-masing siswa pada kelompok pertama dan kelompok kedua dapat menyatakan bahwa kelompok tersebut setara. Berdasarkan teknik matching yang telah dilakukan untuk menentukan kesetaraan, dari jumlah 40 siswa kelas IVA SD Negeri 3 Ubung dan 37 siswa kelas IVB SD Negeri 6 Ubung diperoleh 33 pasang siswa yang memiliki nilai yang sama. Jadi sampel penelitian ini berjumlah 66 siswa, yaitu 33 siswa dari kelompok kontrol dan 33 siswa dari kelompok eksperimen yang dapat dinyatakan setara. Setelah sampel diketahui setara, maka selanjutnya dilakukan pengundian kembali diperoleh hasil SD Negeri 6 Ubung sebagai kelompok eksperimen dan SD Negeri 3 Ubung sebagai kelompok kontrol.

Pada suatu penelitian eksperimen perlu dilakukan pengendalian terhadap validitas penelitian. Validitas penelitian adalah kemampuan peneliti untuk mengungkapkan secara tepat yang ingin diteliti (Dantes, 2014:3). Validitas yang terkait dengan penelitian dapat dibedakan menjadi dua, yaitu validitas internal dan validitas eksternal. Pada penelitian ini ancaman validitas internal yang dikontrol terdiri dari karakteristik subjek dikendalikan dengan cara menyetarakan kelompok menggunakan teknik matching, instrumentasi dikendalikan dengan menggunakan instrumen yang telah dijudges secara teoritik dan divalidasi secara empirik, testing dikendalikan dengan menganalisis skor perolehan ternormalisasikan (gain score normalization) sebagai data penelitian, sejarah dikendalikan dengan cara guru yang melakukan perlakuan pada kelompok eksperimen dan kelompok kontrol memiliki kualifikasi jenjang pendidikan serta pengalaman yang sama, kematangan dikendalikan dengan penggunaan waktu perlakuan hanya sebanyak 6 kali pada kelompok kontrol dan 6 kali 
kelompok eksperimen, dan sikap subjek dapat dikendalikan dengan mengupayakan siswa agar mengganggap pembelajaran yang dilakukan suatu hal yang rutin dengan menggunakan guru kelas. Validitas eksternal yang dikontrol terdiri dari interaksi antara seleksi subjek dengan perlakuan dapat dikendalikan dengan menggunakan siswa sebagai subjek penelitian dan waktu dalam memberikan perlakuan telah sesuai dengan silabus maupun kurikulum yang ada di sekolah, dan hubungan antara setting penelitian dengan perlakuan dapat dikendalikan dengan cara membatasi populasi dengan memperhatikan kelas, usia subjek dan materi pembelajaran yang sama.

Data yang dianalisis dalam penelitian ini adalah data mengenai kompetensi pengetahuan IPA siswa. Metode pengumpulan data yang digunakan pada penelitian ini adalah metode tes. Data tentang kompetensi pengetahuan IPA dikumpulkan melalui instrumen penelitian yaitu tes kompetensi pengetahuan IPA. Instrumen yang digunakan untuk mengetahui kompetensi pengetahuan IPA berupa butir tes yang dikemas menjadi satu perangkat tes yaitu tes kompetensi pengetahuan IPA. Dalam penelitian ini, tes kompetensi pengetahuan IPA disusun oleh peneliti sendiri. Menurut Suharsimi (2015:67) menyatakan bahwa "tes merupakan alat atau prosedur yang digunakan untuk mengetahui atau mengukur sesuatu dalam suasana, dengan cara dan aturan aturan yang sudah ditentukan". Jenis tes yang digunakan dalam penelitian ini adalah tes objektif dalam bentuk pilihan ganda biasa. Sebelum tes digunakan dilakukan validasi untuk menentukan layak tidaknya suatu instrumen yang terdiri dari uji validitas, uji reliabilitas, uji daya beda soal dan uji taraf kesukaran. Menurut Sukardi (2012:122), validitas suatu instrumen adalah derajat yang menunjukkan dimana suatu tes dapat mengukur apa yang hendak diukur. Uji validitas yang digunakan dalam penelitian ini yaitu validitas isi dan validitas butir. Uji validitas isi dalam penelitian ini adalah merujuk pada muatan materi IPA sesuai dengan kompetensi dasar dan indikator yang tertera dalam kurikulum. Hal ini akan dituangkan dalam bentuk kisi-kisi yang telah disesuaikan dengan bahan pembelajaran pada penelitian. Validitas butir mencangkup soal yang harus diujicobakan. Dalam menguji validitas butir tes objektif pilihan ganda biasa untuk mengukur penguasaan kompetensi pengetahuan IPA dihitung dengan menggunakan rumus korelasi point biserial $\left(\mathrm{r}_{\mathrm{pbi}}\right.$ ). Dari 40 butir tes yang diujikan diperoleh hasil 30 butir tes yang valid.

Suatu alat ukur dikatakan reliabel itu apabila alat ukur itu diujikan pada objek atau subjek yang sama secara berulang-ulang hasilnya akan sama, konsisten dan stabil (Yusuf, 2015:74). Uji reliabilitas dilakukan terhadap butir soal yang valid saja, dengan demikian uji reliabilitas bisa dilakukan setelah dilakukan uji validitas. Uji reliabilitas tes yang bersifat dikotomi dan heterogen ditentukan dengan rumus Kuder Richadson (KR-20). Berdasarkan analisis yang dilakukan tes kompetensi pengetahuan IPA layak digunakan sebagai instrumen penelitian.

Dalam menganalisis butir soal disebutkan bahwa soal yang baik adalah soal yang dapat membedakan anak yang berkemampuan tinggi dan anak yang berkemampuan rendah, dilihat dari dapat tidaknya mengerjakan soal itu. "Daya beda soal adalah kemampuan sesuatu soal yang membedakan antara siswa yang pandai (berkemampuan tinggi) dengan siswa yang bodoh (berkemampuan rendah)" Suharsimi (2015:226). Berdasarkan analisis diperoleh 12 soal dengan kriteria cukup, 17 soal dengan kriteria baik, dan 1 soal dengan kriteria baik sekali.

Tingkat kesukaran merupakan bilangan yang menunjukkan sukar dan mudahnya sesuatu soal. Berdasarkan hasil analisis tingkat kesukaran diperoleh 2 soal dengan kriteria sukar, 14 soal dengan kriteria sedang, dan 12 soal dengan kriteria mudah. Sedangkan analisis tingkat kesukaran perangkat tes diperoleh dengan kriteria sedang.

Pada penelitian ini, data yang dikumpulkan dianalisis dari hasil pretest dan posttest menggunakan gain skor yang dinormalisasi. Nilai pretest dan posttest pada dua kelompok, yaitu kelompok kontrol dan kelompok eksperimen ini akan dinormalisasi dengan cara menggunakan rumus gain skor yang dinormalisasi. Setelah diketahui gain skor yang dinormalisasi, dilanjutkan dengan analisis statistik inferensial untuk menganalisis data dalam membuat kesimpulan secara umum. "Analisis statistik inferensial adalah suatu cara pengolahan data yang dilakukan dengan jalan menerapkan rumus-rumus statistik inferensial untuk menguji suatu hipotesis penelitian yang diajukan peneliti dan kesimpulan ditarik berdasarkan hasil pengujian terhadap hipotesis" (Agung, 2014:110). Pada penelitian ini diukur terlebih dahulu uji prasyarat analisis yang terdiri dari uji normalitas sebaran data dan uji homogenitas varians sebelum uji hipotesis dianalisis dengan uji t (t-test). Uji normalitas dilakukan untuk mengetahui sebaran data kompetensi pengetahuan IPA siswa masing-masing kelompok berdistribusi normal atau tidak sehingga dapat menentukan teknik analisis datanya. Untuk menghitung uji normalitas dalam penelitian ini menggunakan Chi-Kuadrat. Kriteria pengujian adalah jika harga $\chi_{\square \text { itung }}^{2} \leq$ $\chi_{\text {tabel }}^{2}$ maka $\mathrm{H}_{0}$ diterima (gagal ditolak) dan $\mathrm{H}_{\mathrm{a}}$ ditolak yang berarti sebaran data berdistribusi normal, sedangkan jika harga $\chi_{\square \text { itung }}^{2}>\chi_{\text {tabel }}^{2}$ maka $\mathrm{H}_{0}$ ditolak dan $\mathrm{H}_{\mathrm{a}}$ diterima (gagal ditolak) yang berarti data tidak berdistribusi normal. Uji homogenitas dilakukan untuk menunjukkan bahwa perbedaan yang terjadi pada uji hipotesis benarbenar terjadi akibat adanya perbedaan varians antar kelompok, bukan sebagai akibat perbedaan dalam kelompok. Uji homogenitas dapat dilakukan apabila kelompok data tersebut berdistribusi normal. Uji homogenitas varians dilakukan dengan uji Fisher (F). Kriteria pengujian, jika harga $F_{\text {hitung }}<F_{\text {tabel }}$ maka sampel homogen. Analisis data yang digunakan untuk menguji hipotesis penelitian ini adalah uji beda mean (uji t). Uji Hipotesis 
menggunakan uji-t dengan rumus separated varian. Rumus uji-t dengan rumus separated varian digunakan karena jumlah anggota sampel sama $\mathrm{n}_{1}=\mathrm{n}_{2}$ dan varian homogen. Dengan kriteria jika harga $\mathrm{t}_{\text {hitung }} \leq \mathrm{t}_{\text {tabel }}$, maka $\mathrm{H}_{\mathrm{o}}$ diterima dan $\mathrm{H}_{\mathrm{a}}$ ditolak, dan jika harga $t_{\text {hitung }}>\mathrm{t}_{\text {tabel }}$ maka $\mathrm{H}_{\mathrm{o}}$ ditolak dan $\mathrm{H}_{\mathrm{a}}$ diterima. Pada taraf signifikan 5\% dengan $\mathrm{dk}=\mathrm{n}_{1}+\mathrm{n}_{2}-2$.

\section{Hasil Dan Pembahasan}

Data hasil kompetensi pengetahuan IPA diperoleh dengan perhitungan gain skor yang dinormalisasi. Pada penelitian ini yang digunakan sebagai kelompok eksperimen yaitu kelas IVB SD Negeri 6 Ubung dengan data gain skor kompetensi pengetahuan IPA memiliki nilai maksimum 0,9, nilai minimum 0,3, rata-rata 0,56, standar deviasi 0,16 dan varians 0,026. Sedangkan data gain skor kelompok kontrol yaitu kelas IVA SD Negeri 3 Ubung memiliki nilai maksimum 0,7 , nilai minimum 0,1 , rata-rata 0,49 , standar deviasi 0,17 , dan varians 0,029 . Berdasarkan hasil tersebut dapat diketahui rata-rata kompetensi pengetahuan IPA siswa kelompok eskperimen $\bar{X}=0,56>\bar{X}=0,43$ siswa kelompok kontrol. Setelah diketahui hasil gain skor kompetensi pengetahuan IPA yang di peroleh kedua kelompok dilakukan uji prasyarat yang meliputi uji normalitas sebaran data dan uji homogenitas varians.

Hasil uji normalitas sebaran data kompetensi pengetahuan IPA pada kelompok eksperimen diperoleh $x^{2}$ hitung $=8,42$, kemudian dibandingkan dengan taraf signifikan 5\% dan derajat kebebasan $(\mathrm{dk})=5$ diperoleh $x_{\text {tabel }}^{2}$ $=11,07$, karena $x^{2}$ hitung $=8,42<x_{\text {tabel }}^{2}=11,07$ maka $\mathrm{h}_{0}$ diterima (gagal ditolak). Ini berarti sebaran data kompetensi pengetahuan IPA pada kelompok eksperimen berdistribusi normal. Sedangkan pada kelompok kontrol diperoleh $x^{2}$ hitung $=7,99$, kemudian dibandingkan dengan taraf signifikan 5\% dan derajat kebebasan $(\mathrm{dk})=$ 5 diperoleh $x_{\text {tabel }}^{2}=11,07$, karena $x_{\text {hitung }}^{2}=7,99<x_{\text {tabel }}^{2}=11,07$ maka $\mathrm{h}_{0}$ diterima (gagal ditolak). Ini berarti sebaran data kompetensi pengetahuan IPA pada kelompok kontrol berdistribusi normal.

Pada uji homogenitas diperoleh $F_{\text {hitung }}=1,12$, sedangkan pada taraf signifikansi 5\% dengan derajat kebebasan pembilang 33-1=32 dan derajat kebebasan penyebut 33-3 =32 diperoleh $F_{\text {tabel }}=1,84$. Hal ini berarti $\mathrm{F}_{\text {hitung }}=1,12<\mathrm{F}_{\text {tabel }}=1,84$, sehingga data kedua kelompok memiliki varians yang homogen .

Analisis statistik yang digunakan untuk menguji hipotesis penelitian ini adalah uji-t dengan rumus separated varians. Adapun hasil analisis hipotesis menggunakan uji-t disajikan pada tabel 1 .

Tabel 1.

Hasil Analisis Uji-t Kelompok Sampel Penelitian

\begin{tabular}{|c|c|c|c|c|c|c|c|}
\hline No & Kelompok Sampel & $\mathrm{N}$ & $\mathrm{Dk}$ & $\bar{X}$ & $\mathrm{t}_{\text {hitung }}$ & $\mathrm{t}_{\text {tabel }}$ & Keterangan \\
\hline 1. & Eksperimen & 33 & \multirow{2}{*}{64} & 0,56 & \multirow{2}{*}{3,25} & 2,00 & $\mathrm{H}_{0}$ ditolak \\
\cline { 1 - 2 } & Kontrol & 33 & & 0,49 & & & \\
\hline
\end{tabular}

Berdasarkan hasil analisis uji hipotesis diperoleh $t_{\text {hitung }}=3,25$ sedangkan pada taraf signifikansi $5 \%$ dan $\mathrm{dk}=64$ diperoleh nilai $\mathrm{t}_{\text {tabel }}=2,00$ sehingga $\mathrm{t}_{\text {hitung }}=3,25>\mathrm{t}_{\text {tabel }}=2,00$ maka $\mathrm{H}_{0}$ ditolak dan $\mathrm{H}_{\mathrm{a}}$ diterima. Hal ini berarti terdapat perbedaan yang signifikan kompetensi pengetahuan IPA antara kelompok eksperimen dan kelompok kontrol pada kelas IV SD Gugus Kolonel I Gusti Ngurah Rai Denpasar Utara tahun pelajaran 2016/2017. Rata-rata kompetensi pengetahuan IPA juga menunjukkan siswa kelompok eskperimen $\bar{X}=0,56>$ $\bar{X}=0,43$ siswa kelompok kontrol sehingga dapat disimpulkan bahwa model pembelajaran student facilitator and explaining berbantuan peta konsep berpengaruh terhadap kompetensi pengetahuan IPA siswa kelas IV Gugus Kolonel I Gusti Ngurah Rai Denpasar Utara tahun pelajaran 2016/2017.

Berdasarkan hasil temuan pada kedua kelompok dapat diketahui bahwa kedua kelompok yang awalnya memiliki kemampuan setara, lalu setelah diberikan perlakuan maka perolehan nilai kompetensi pengetahuan IPA mengalami perbedaan. Kompetensi pengetahuan siswa pada kelompok eksperimen lebih baik apabila dibandingkan dengan kompetensi pengetahuan siswa pada kelompok kontrol. Hal ini dapat dilihat juga dari ratarata siswa kelompok eksperimen dan rata-rata siswa kelompok kontrol. Perbedaan hasil kompetensi pengetahuan dengan perolehan gain skor yang dinormalisasi, rata-rata pada kelompok eksperimen lebih tinggi dibandingkan kelompok kontrol disebabkan oleh perlakuan berupa model pembelajaran student facilitator and explaining berbantuan peta konsep khususnya muatan materi IPA yang diberikan pada kelompok eksperimen.

Pada kegiatan pembelajaran di kelompok eksperimen menggunakan model pembelajaran student facilitator and explaining berbantuan peta konsep berjalan dengan optimal dan kondusif. Hal ini disebabkan model pembelajaran student facilitator and explaining berbantuan peta konsep merupakan suatu model yang memberikan kesempatan kepada siswa menjadi fasilitator dan melatih siswa aktif untuk dapat menyajikan materi 
yang memuat berbagai informasi dalam bentuk peta konsep untuk memperjelas pemahaman yang dimiliki oleh siswa. Langkah-langkah pada model pembelajaran student facilitator and explaining juga membuat siswa lebih aktif karena dikemas dengan kegiatan pembelajaran yang membuat siswa ingin bertanya dan mencari informasi sendiri serta menyampaikan pendapatnya, sehingga dalam penyampaian informasi dari siswa menjadi lebih bermakna. Model pembelajaran ini dipadukan dengan media peta konsep untuk memudahkan siswa memahami materi khususnya pada muatan materi IPA tema tempat tinggalku menjadi lebih sederhana. Dengan demikian, pembelajaran menjadi lebih bermanfaat, menyenangkan serta berpengaruh positif terhadap kompetensi pengetahuan IPA siswa. Sedikit perbedaan dengan pembelajaran yang berlangsung pada kelompok kontrol. Kegiatan pembelajaran pada kelompok kontrol berjalan kurang optimal karena hanya mengacu pada lima pengalaman belajar yaitu mengamati, menanya, mengumpulkan informasi, mengasosiasi, dan mengomunikasikan. Pembelajaran menggunakan model pembelajaran student facilitator and explaining berbantuan peta konsep pada muatan materi IPA memberikan kesempatan yang lebih luas kepada siswa untuk mengonstruksikan pengetahuannya melalui berbagai kegiatan bermakna dan teratur yang tentunya menggembirakan bagi siswa pada setiap langkah pembelajarannya. Dengan demikian, perbedaan hasil kompetensi pengetahuan IPA dapat terlihat dari langkah pembelajaran yang dilakukan pada kedua kelompok tersebut, hasil analisis uji hipotesis, dan nilai rata-rata kelompok eksperimen maupun kelompok kontrol.

Hasil temuan pada penelitian ini memiliki persamaan dengan penelitian sebelumnya yang relevan dan memperkuat hasil penelitian yang diperoleh. Hal tersebut didukung hasil penelitian yang diajukan oleh Rianti (2017) terdapat perbedaan kemampuan pemahaman konsep IPA siswa yang menggunakan model pembelajaran student facilitator and explaining dan menggunakan pembelajaran konvensional pada siswa kelas IV SDN Serdang I tahun ajaran 2015/2016 dengan diperoleh $t_{\text {hitung }}=4,062>t_{\text {tabel }}=1,671$. Dengan demikian, pembelajaran menggunakan model pembelajaran student facilitator and explaining berbantuan peta konsep pada penelitian ini memiliki keunggulan yakni dapat meningkatkan keaktifan siswa dalam memberikan pendapat dengan menggunakan cara dan bahasanya sendiri. Model ini juga efektif dalam melatih siswa berbicara, sehingga siswa tidak lagi menjadi objek pembelajaran tetapi sebagai subjek yang mengalami, menemukan, mengkonstruksikan materi yang dipelajarinya.

\section{Simpulan Dan Saran}

Berdasarkan analisis uji $\mathrm{t}$ diperoleh hasil $\mathrm{t}_{\text {hitung }}=3,25$, sedangkan $\mathrm{t}_{\text {tabel }}=2,00$ pada taraf signifikansi $5 \%$ dengan $\mathrm{dk}=64$. Oleh karena nilai $\mathrm{t}_{\text {hitung }}=3,25>\mathrm{t}_{\mathrm{tabel}}=2,00$, maka $\mathrm{H}_{0}$ ditolak dan $\mathrm{H}_{\mathrm{a}}$ diterima. Hal ini membuktikan bahwa terdapat perbedaan yang signifikan kompetensi pengetahuan IPA antara kelompok eksperimen dan kelompok kontrol pada kelas IV SD Gugus Kolonel I Gusti Ngurah Rai Denpasar Utara tahun pelajaran 2016/2017. Nilai rata-rata juga menunjukkan bahwa kompetensi pengetahuan IPA yang diperoleh siswa kelompok eskperimen $\bar{X}=0,56>\bar{X}=0,43$ siswa kelompok kontrol. Dengan demikian dapat disimpulkan bahwa model pembelajaran student facilitator and explaining berbantuan peta konsep berpengaruh terhadap kompetensi pengetahuan IPA siswa kelas IV Gugus Kolonel I Gusti Ngurah Rai Denpasar Utara tahun pelajaran 2016/2017.

Berdasarkan hasil penelitian yang diperoleh, maka saran yang dapat diajukan yaitu kepada siswa disarankan agar berpartisipasi aktif dan dapat mengembangkan kemampuannya dalam kegiatan pembelajaran menggunakan model pembelajaran student facilitator and explaining berbantuan peta konsep, sehingga dapat melatih siswa untuk menyampaikan pendapatnya untuk membangun pengetahuan sendiri, kepada guru agar lebih menambah wawasan dan pengetahuan tentang mengembangkan inovasi dan merancang pembelajaran untuk memberikan fasilitas berupa sumber belajar serta kesempatan yang lebih besar bagi siswa pada pembelajaran dengan menggunakan model pembelajaran student facilitator and explaining berbantuan peta konsep sehingga tercipta pembelajaran bermakna, kepada kepala sekolah disarankan agar dapat menggunakan hasil penelitian ini sebagai pendukung sumber belajar guru dalam meningkatkan pembelajaran sehingga dapat meningkatkan mutu dan kualitas sekolah yang lebih unggul dan inovatif, dan kepada peneliti lain disarankan agar hasil penelitian ini digunakan sebagai referensi untuk melaksanakan penelitian selanjutnya pada tema dan kegiatan pembelajaran lainnya untuk memperoleh hasil yang lebih baik.

\section{Daftar Pustaka}

Agung, A. A. Gede. 2011. Pengantar Evaluasi Pendidikan. Singaraja: FIP Undiksha.

Agung, A. A. Gede. 2014. Metodelogi Penelitian Pendidikan. Malang: Aditya Media Publising.

Aqib, Zainal. 2015. Model-Model, Media, dan Strategi Pembelajaran Konstektual (Inovatif). Bandung: Yrama Widya.

Arikunto, Suharsimi. 2015. Dasar-Dasar Evaluasi Pendidikan. Jakarta: PT Bumi Aksara.

Dantes, Nyoman. 2014. Analisis dan Design Eksperimen. Singaraja: Program Pasca Sarjana Undiksha. 
Darmadi, Hamid. 2014. Metode Penelitian Pendidikan dan Sosial. Bandung: Alfabeta.

Daryanto. 2014. Pendekatan Pembelajaran Saintifik. Yogyakarta: Gava Media.

Huda, Miftahul. 2013. Model-model Pengajaran dan Pembelajaran. Yogyakarta: Pustaka Pelajar.

Kurniasih, Imas dan Berlin Sani. 2014. Sukses Mengimplentasikan Kurikulum 2013. Jakarta: Kata Pena.

Nurgiantoro, Burhan. 2016. Penilaian Pembelajaran Bahasa Berbasis Kompetensi. Yogyakarta: BPFE Yogyakarta.

Rianti, dkk. 2017. "Pengaruh Model Student Facilitator and Explaining (SFAE) Terhadap Pemahaman Konsep Siswa Kelas IV Pada Mata Pelajaran IPA". Jurusan Pendidikan Guru Sekolah Dasar Universitas Sultan Ageng Tirtayasa, Volume 3, Nomor 1 (Hlm. 64). Tersedia pada https://jurnal.untirta.ac.id (diakses tanggal 12 Juni 2017)

Samatowa, Usman. 2016. Pembelajaran IPA di Sekolah Dasar. Jakarta: PT Indeks.

Setyosari, Punaji. 2015. Metode Penelitian Pendidikan dan Pengembangan. Jakarta: Prenadamedia Group.

Shoimin, Aris. 2014. 68 Pembelajaran Inovatif dalam Kurikulum 2013. Yogyakarta: Ar Ruzz Media.

Suardi. 2016. Pengantar Pendidikan. Jakarta: PT Indeks.

Sugiyono. 2016. Metode Penelitian Pendidikan Pendekatan Kuantitatif, Kualitatif, dan R \& D. Bandung: Alfabeta.

Sukardi. 2012. Metodologi Penelitian Pendidikan. Jakarta: PT Bumi Aksara

Yusuf, Muri. 2015. Asesmen dan Evaluasi Pendidikan. Jakarta: Prenadamedia Grup. 